\title{
NATURE-BASED TOURISM ENTERPRISE ADAPTIVE RESPONSES TO COVID-19 IN SOUTH AFRICA
}

\author{
Julia K. GIDDY \\ University of Mpumalanga, School of Biology \& Environmental Sciences, Mbombela, South Africa, \\ University of Johannesburg, School of Tourism \& Hospitality, Johannesburg, South Africa, e-mail: julia.giddy@ump.ac.za
}

Jayne M. ROGERSON*

University of Johannesburg, School of Tourism \& Hospitality, Johannesburg, South Africa, e-mail: jayner@uj.ac.za

\begin{abstract}
Citation: Giddy, J.K., \& Rogerson, M.J. (2021). NATURE-BASED TOURISM ENTERPRISE ADAPTIVE RESPONSES TO COVID-19 IN SOUTH AFRICA. GeoJournal of Tourism and Geosites, 36(2spl), 698-707. https://doi.org/10.30892/gtg.362spl18-700
\end{abstract}

\begin{abstract}
COVID-19 is forcing a re-orientation of tourism research agendas. Emerging themes relate to ramification, transformation and adaptation. The aim of this paper is to contribute to the research cluster on adaptation by examining tourism business adaptive responses to COVID-19 through the lens of a case study destination in the global South, namely Bushbuckridge in Mpumalanga Province, South Africa. The methods implemented were qualitative, using semi-structured interviews. Data was analysed from 20 interviews conducted with enterprise owners or managers in a nature tourism destination which is one of South Africa's tourism-dependent areas and thus most exposed to the negative impacts of COVID-19. The results show that adaptation to the crisis has been challenging because of the financial impacts experienced by these enterprises in the wake of minimal government support. The enterprise adaptive responses included staff reductions and wage cuts, adjustments towards the domestic market through price cutting and changes in marketing as well as adjusted tourism product offerings towards an emerging Black middle class domestic market. Of critical importance is the finding that these adaptive measures cannot replace the revenues formerly generated from the international tourism market. Accordingly, without a change in government policy and the availability of direct government financial support, there is a danger that in the short term the tourism product base will be diminished as many lodges and other tourism businesses are in danger of permanent closure.
\end{abstract}

Key words: $x$ COVID-19; nature tourism; business adaptation; South Africa

\section{INTRODUCTION}

The United Nations Conference on Trade and Development regards COVID-19 as "a health and economic crisis on a global scale" (UNCTAD, 2020: 7). Indeed, the pandemic has posed critical international health challenges and is severely threatening the achievement of the United Nations Sustainable Development Goals for ending poverty by 2030 as increased global poverty is projected for the first time since 1990 (Buheji et al., 2020; Grech et al., 2020; Nicola et al., 2020). The challenge of COVID-19 for poverty and the need for appropriate responses by all key stakeholders is especially great in Africa, the world's poorest continent, which it is projected to "experience the greatest economic loss in recent years" (Buheji et al., 2020: 216). The OECD (2020a) argues that the current crisis threatens to erase years of development gains in Africa.

For the global tourism industry COVID-19 has produced a profound crisis as it has effectively halted the operations of the tourism sector (Hall et al., 2020; Gössling et al., 2021; Kvirkvelia and Tsitsagi, 2021; Sharma et al., 2021). Certain scholars are reflecting that as COVID-19 has catastrophically disrupted consumer demand and supply chains, it represents a turning point for global tourism (Bianchi, 2020; Sigala, 2020). For example, as observed by Bianchi (2020: 80) "in contrast to previous disruptions, whether brought about by terrorism, natural disasters, financial crises or indeed previous pandemics, the outbreak of the COVID-19 pandemic has precipitated an unprecedented shutdown of travel and tourist destinations on a truly global scale". Implementation of strategies to flatten the COVID-19 curve such as lockdowns, stay-at-home orders, social distancing or travel and mobility restrictions have resulted in the temporary closure (and increasingly permanent closure) of many tourism establishments (Gursoy and Chi, 2020). Arguably, the global crisis accompanying the pandemic's spread is producing a shift in research agendas and changes in the topics of business and tourism research (Brouder, 2020; Kock et al., 2020; Persson-Fischer and Liu, 2021; Wood, 2021). Verma and Gustafson (2020) conducted a bibliometric analysis of COVID-19 scholarship in the domain of business and management and revealed four major topical foci surrounding overall impacts, technology, supply chain management and the service industry, including tourism and hospitality. For tourism scholars COVID-19 represents a critical challenge as "research that contributes to industry practice will need to reorient the focus of studies, given that the industry will undoubtedly change with new normal practices in place” (Kwok and Koh, 2021: 386).

An international thematic content analysis of COVID-19 specific literature on tourism disclosed a number of critical themes that are emergent as well as new areas that merit further attention. Three thematic clusters of work were distilled in the content analysis performed by Kwok and Koh (2021).The first relates to 'ramification' which encompasses empirical assessments of the pandemic's impact on tourism, including changes in tourism demand as well as evaluations of the impacts

* Corresponding author 
of government support (see eg. Deb and Nafi, 2020; Kusumaningrum and Wachyuni, 2020; Rogerson and Rogerson, 2020a; Rutynskyi and Kushniruk, 2020). The second relates to 'transformation' which relates to a major corpus of work which is forward-looking to the extent that it is analysing the prospects for restructuring future tourism and offering post-pandemic outlook analysis (Bianchi, 2020; Brouder, 2020; Higgins-Desbiolles, 2020a, 2020b; Niewiadomski, 2020).

The third cluster concerns 'adaptation' which is a stream of investigations including responses in terms of the application of new technologies as well as explorations of the capacity of destinations and tourism businesses to adapt to change and build resilience (see eg. Seyitoğlu and Ivanov, 2020; Bressan et al., 2021). The aim in this paper is to contribute to this third research cluster by examining tourism businesses adaptive responses to COVID-19 through the lens of a destination case study in the global South, namely Bushbuckridge in the Mpumalanga Province, South Africa. Within Africa, South Africa is the worst affected country by COVID-19 health impacts as well as with devastating consequences for the tourism sector (Rogerson and Rogerson, 2020b, 2021a). Rogerson and Baum (2020) suggest that an appropriate African research response to COVID-19 in the context of tourism must embrace a genuine transdisciplinary approach and draw in researchers who would not, historically, have operated in the tourism space. In addition, it requires a resetting of the thematic foci of the African tourism research agenda. In the wake of the economic crisis generated by the pandemic in Africa as a whole, and South Africa in particular, the relevance of pursuing research on tourism businesses adaptation as part of this emerging new agenda is self-evident.

\section{LITERATURE REVIEW}

As highlighted by Kwok and Koh (2021: 390) in their thematic content analysis of COVID-19 tourism scholarship questions around "mitigation efforts" and the adaptation of destinations and businesses are issues in need of further investigation. At the outset the adaptation of businesses must be understood in relation to the ramifications COVID-19 and most especially in terms of changing consumer demand. The magnitude and duration of the pandemic is reshaping former patterns of tourism demand and supply which need to be understood. As Kock et al. (2020: 1) stress COVID-19 "will reshuffle taken-for-granted determinants of tourism as we know it". The pandemic represents a paradigm shift for research about tourist behaviour as it is viewed that "what was previously taken for granted may not hold anymore in the COVID-19 era" (Kock et al., 2020: 2). Zenker and Kock (2020) identify the emergence of a new 'tourism psyche' in the wake of the COVID-19 pandemic to which tourism businesses need to adapt. Across international scholarship several dimensions of this new tourism psyche are identified (Rogerson and Rogerson, 2021b). Among the most important are that exposure to a disease threat can make people more 'collectivistic' by giving preference to domestic over foreign travel and seeking to support their own local economy in a form of behaviour which is styled as 'tourism ethnocentrism' defined as "an individual's prescriptive beliefs and felt moral obligation to support the domestic tourism economy" (Kock et al., 2019a: 427-428). Second, is the "home-is-saferthan-abroad bias' in terms of which tourists regard their home country as a 'safe' destination and that "home is safe, no matter where home is" (Wolff et al., 2020). Three, COVID-19 threats make people alert of and avoid crowded situations, a mind shift about 'crowdedness' that results in preferences for visits to more remote and less populated tourist areas (Rogerson and Rogerson, 2021b, Rogerson, 2021). The new tourism psyche around perceived risk underpins observed changes by international researchers in consumer mobilities and patterns of demand. In relation to changing mobilities the most significant finding is that consumers are pivoting away from modes of transport that involve higher perceived risks and exposure to other tourists - most notably cruise ships, air travel, as well as certain public bus and rail transport - and towards private forms of mobility, including private cars, rented cars and, in some countries, for campervans (Rogerson and Rogerson, 2021b).

Concerning changing patterns of demand and destinations, the emerging new tourism psyche together with shifting travel mobilities is resulting in new patterns of consumer demand for particular forms of tourism products and destinations. Safety, cleanliness and hygiene management are key drivers of new consumer demand intentions. The OECD (2020b) and United Nations World Tourism Organisation (UNWTO, 2020) argue that the COVID-19 pandemic highlights, more than ever, the role of tourism in rural and remote areas which offer significant opportunities for recovery as, with changes in consumer demand, tourists look for less populated destinations and open-air experiences and activities. Nature-based and ecotourism areas are projected to increase in demand, and in the (post) COVID-19 environment a highly significant role will be assumed by 'green spaces' as a whole and by national parks and nature reserves in particular. Overall, as a reflection of the new tourism psyche about crowdedness, it is evident that natural areas "are likely to exert a stronger pull than before, with travellers and tourists seeking to avoid crowds and polluted cities" (Spalding et al., 2020: 2). Finally, the importance of reduced contact or of 'untact tourism' is a further critical consumer trend that businesses must adapt to in their operations (Bae and Chang, 2020; Rogerson and Rogerson, 2021b). As compared to this burgeoning literature on the ramifications of COVID-19 on changing tourism demand much less attention as yet has been given to detailed investigations of supply-side responses and tourism enterprise adaptations to the changing environment occasioned by the pandemic. The richest studies are those by Alonso et al. (2020) and Alonso et al. (2021). These investigations underscore that financial impacts and uncertainty are central for driving adaptation measures. Against this backcloth our case study of Bushbuckridge is of particular interest for scholarship on tourism businesses adaptation because of its concentration on nature-based tourism, an activity which is projected to increase in consumer demand. Further it is a nature-based tourism destination in South Africa, where the contraction of tourism and loss of revenues experienced by tourism businesses has highly significant implications for communities living in and around protected areas set aside for nature-based tourism (Hockings et al., 2020).

\section{CASE STUDY AND METHODS}

The case study area of Bushbuckridge has been described by Thornton (2002: 219) as "a complex and sensitive environment of human settlement, commercial agriculture and nature reserves". In terms of location the area is within the 
Mpumalanga Province and the largest closest centre is Mbombela, the provincial capital (Figure 1). The area is geographically distant from South Africa's major metropolitan areas but close to Kruger National Park, one of the country's most iconic tourist attractions for nature-based tourism. The region hosts several game reserves and nature-based tourism conservation projects. Since democratic transition in 1994 tourism has "vastly increased" with over 30 new safari lodges which opened in the area during the first decade of political change (Thornton, 2002: 219). The tourism sector thus became the lifeblood of the local economy (Shackleton, 2000). One recent study of local economic development in this municipality confirms tourism's importance for the Bushbuckridge local economy (Nkuna, 2017). Another investigation points to the challenges that face small business development in the area, including for tourism enterprises (Mukwarami et al., 2020). The importance of tourism for local development and livelihoods must be understood in the context that the locality of Bushbuckridge which experiences chronic high levels of poverty and unemployment (Niyimbanira, 2016).

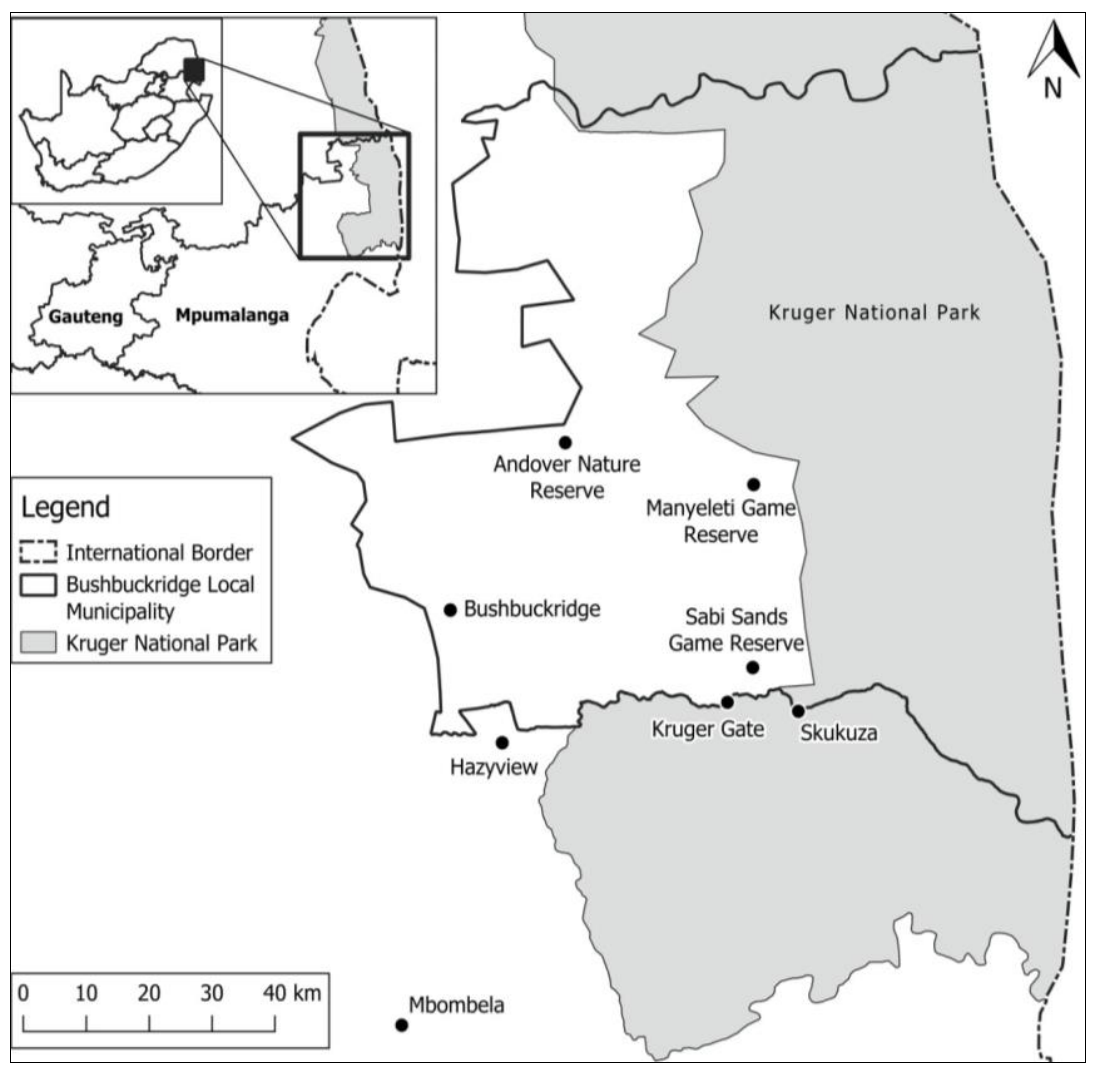

Figure 1. Bushbuckridge Location Map (Source: Authors)
Table 1. Profile of Bushbuckridge Tourism Economy in Pre-COVID 2018 (Source: Authors based on unpublished IHS Global Insight data)

\begin{tabular}{|c|c|}
\hline Total of Tourist Trips & 361297 \\
\hline Number of Leisure Trips & $\begin{array}{c}60602 \\
(16.8 \%)\end{array}$ \\
\hline Number of Business Trips & $\begin{array}{l}17564 \\
(4.9 \%)\end{array}$ \\
\hline $\begin{array}{l}\text { Number of Visiting Friends and } \\
\text { Relatives Trips }\end{array}$ & $\begin{array}{l}243799 \\
(67.5 \%) \\
\end{array}$ \\
\hline Domestic trips & $\begin{array}{l}268458 \\
(74.3 \%)\end{array}$ \\
\hline International trips & $\begin{array}{l}92839 \\
(25.7 \%)\end{array}$ \\
\hline Total of Bednights & 1391803 \\
\hline Domestic Bednights & $\begin{array}{l}566897 \\
(40.7 \%)\end{array}$ \\
\hline International Bednights & $\begin{array}{l}824906 \\
(59.3 \%)\end{array}$ \\
\hline $\begin{array}{l}\text { Total Tourism Spend (R'1000 } \\
\text { Current Prices) }\end{array}$ & 5394177 \\
\hline $\begin{array}{l}\text { Total tourism Spend as \% of } \\
\text { Gross Domestic Product (GDP) }\end{array}$ & $32.2 \%$ \\
\hline
\end{tabular}

The local municipality's Integrated Development Plan reinforces the significance of growing the tourism sector for driving local economic development and addressing the area's problems of poverty and dearth of employment opportunities (Bushbuckridge Local Municipality, 2017). Nevertheless, for Khoza (2016: 193) tourism is as yet "underdeveloped" in the Bushbuckridge Local Municipality with core challenges relating to infrastructure shortcomings, poor signage and lack of skilled labour. Despite this, the local municipality ranks as the fifthmost tourism dependent in the country (Rogerson and Rogerson, 2020a). As a region of outmigration, Bushbuckridge experiences a reverse flow of large numbers of seasonal Visiting Friends and Relatives (VFR) domestic travellers into the area, shown in Table 1 below (Rogerson, 2017). For employment and income generation, however, the area is highly dependent on leisure tourism with major reliance, in the pre-COVID-19 era, on the segment of international tourism (Rogerson and Rogerson, 2021a). It is also clear that tourism forms a significant portion of the total GDP of the region. Across the area of the local municipality and its surrounds the core tourism product is that of nature-based tourism, most of which feeds into the adjacent Kruger National Park. Khoza (2016: 200) argues further that the area "has a huge ecotourism potential". Indeed, the municipal area enjoys major nature tourism assets which include Manyeleti Game Reserve, Sabi Sand Game Reserve, and Andover Nature Reserve. The local tourism product mix contains attractions and accommodation service offerings which target both high-end international tourists as well as the domestic tourism market (Khoza, 2016; Lubbe et al., 2016). Within the municipality are a wide range of accommodation service providers from, on the one hand, exclusive all-inclusive up-market safari lodges to family-friendly self-catering accommodation to, on the other hand, a range of budget accommodation providers including bush camps, caravan and camping facilities as well as backpacker hostels (Khoza, 2016). As is the case for the tourism sector in South Africa as a whole, tourism in Bushbuckridge and its surrounds has been severely impacted by the pandemic. In interrogating tourism businesses responses to the impacts of the COVID-19 pandemic a qualitative approach was adopted with semi-structured interviews undertaken with a cross-section of 20 key private sector tourism product owners. Many businesses were contacted to participate in the study. The respondents were selected based on their availability as well as taking into consideration a cross-section of different relevant business types in the area. Convenience and snowball sampling techniques were implemented for respondent selection. The interviews were undertaken during the period January-February 2021. Of the total interviews 11 (55 percent) were conducted in-person with respect to essential social distancing; the remainder were telephonic interviews. For many enterprises the necessity for telephonic 
interviews was a result of local flooding of roads which made access impossible for planned face-to-face interviews. The interview schedule was designed to determine issues of COVID-19 responses of enterprises and challenges, the role of government regulation and future business prospects. The data was analysed through thematic content analysis. A content analysis approach was utilised to interrogate the transcribed qualitative interview data.

Businesses included in this investigation consisted of a range of tourism operators based in and around the Bushbuckridge municipality. The study encompassed tourism operators located within the Bushbuckridge municipality as well as those in bordering towns, which feed into the Kruger National Park and from which the majority of staff is based in Bushbuckridge. This included towns such as Hazyview, just over the border of the Bushbuckridge municipality, as well as operators with main offices in Mbombela but which operate in the lower Kruger region, serving parts of the park found within Bushbuckridge, most importantly Paul Kruger gate and Skukuza camp. Of the 20 businesses which were interviewed, most (10) operate out of Hazyview, five were located directly in Bushbuckridge municipality, while the remaining five have offices based in Mbombela. The majority of businesses interviewed were accommodation establishments, mostly lodges due to the nature of accommodation in the area, with another two hotels, one guesthouse and one backpacker hostel. In addition, interviews were also conducted with representatives of two major private game reserves which border Kruger National Park, each of which houses several camps with various accommodation offerings. Other than accommodation, seven businesses were safari and tour operators (with some overlap with accommodation operators), two provide wildlife interactions and one restaurant was included in the research. A profile of the businesses that were interviewed in the Bushbuckridge cluster is given on Table 2.

Table 2. The Sample of Interviewed Enterprises in Bushbuckridge (Source: Authors)

\begin{tabular}{|c|c|c|c|}
\hline Identifier & $\begin{array}{c}\text { Type of } \\
\text { Establishment }\end{array}$ & $\begin{array}{l}\text { Years in } \\
\text { Operation }\end{array}$ & $\begin{array}{c}\text { Number of Permanent } \\
\text { Employees }\end{array}$ \\
\hline B1 & Spa & 10 & 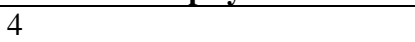 \\
\hline B2 & Wildlife Interaction & 12 & 40 \\
\hline B3 & Hotel & 2.5 & 20 \\
\hline B4 & Lodge & 15 & 1 (previously 7) \\
\hline B5 & Wildlife Interaction & 12 & 5 \\
\hline B6 & Lodge & 12 & 7 \\
\hline B7 & Backpackers & 10 & 5 (previously 10 ) \\
\hline B8 & Safaris/Tours & 27 & 1 \\
\hline B9 & Tours; Guesthouse & 6 & $\begin{array}{l}1 \text { permanent, } \\
3 \text { freelance }\end{array}$ \\
\hline B10 & Game Reserve & 59 & 175 \\
\hline B11 & Safaris/Tours & 7 & 2 permanent, freelance as needed \\
\hline B12 & Lodge & 11 & 28 (previously 38) \\
\hline B13 & Safaris/Tours & 15 & 1 permanent, 14 freelance \\
\hline B14 & $\begin{array}{l}\text { Safaris/Tours; } \\
\text { Lodge }\end{array}$ & 2 & $\begin{array}{l}\text { Lodge - } 28 \text { permanent (previously } \\
31 \text { ); Safaris - } 23 \text { permanent, } \\
10 \text { freelance }\end{array}$ \\
\hline B15 & Safaris/Tours & 11 & 11 permanent, 6 freelance \\
\hline B16 & Lodge & 15 & 17 \\
\hline $\mathrm{B} 17$ & Restaurant & 2 & 2 \\
\hline B18 & Lodge; Restaurant & $\begin{array}{l}\text { Restaurant - } 6 \\
\text { months; } \\
\text { Lodge - } 2 \text { months }\end{array}$ & 170 \\
\hline B19 & Hotel & 10 & 150 \\
\hline $\mathrm{B} 20$ & Game Reserve & 20 & 240 \\
\hline
\end{tabular}

It is evident from Table 2 that there was a wide range in years of operation of the various businesses, with one in operation for 59 years and another having opened as recently as December 2020. Half of the respondents have been in operation for approximately 10-20 years, with another three over 20 years and the remaining seven operating less than 10 years. The sizes of the operators, in terms of staff, also varied significantly albeit these numbers have changed since the onset of the pandemic. Some have employee numbers as high as 240 , while several only have one or two permanent employees (these are largely owner operated). The nature of several of these businesses mean that they engage a number of freelance staff, primarily in the form of game rangers and safari guides. The overall impact of the pandemic from the perception of the Bushbuckridge cluster of respondents was overwhelmingly negative. Several respondents used words such as "disastrous", "devastating" or similar such phrases. Others included phrases such as "unfair" (B16), "life-changing" (B7) or related it to their current financial status, for example "loss of income" (B5).

In general, there was a clear sense of the severity of the impact of the pandemic on these businesses across the board. In the Bushbuckridge area the debilitating impact of the pandemic was exacerbated by the fact that most businesses are dominated by international tourists rather than the domestic market. Of the 20 interviewees only two had a majority share of domestic tourists, namely a wildlife interaction centre and a tour guide/operator out of Bushbuckridge, who mostly takes local tourists to neighbouring countries. Among the remaining businesses, a significant proportion (8 operators) had upwards of $90 \%$ of their market share from international tourists. Another six enterprises said international tourists accounted for more than $80 \%$ of their clients while the remaining six businesses stated that international tourists accounted for between $60 \%$ and $80 \%$ of the clientele. Respondents were probed about their perceptions of government regulations during the pandemic. All but two enterprises stated that the government had negatively impacted their businesses, while one said there were some positives albeit it was mostly negative. These findings confirm those reported both from earlier academic investigations (Rogerson and Rogerson, 2020a, 2020b; Sucheran, 2021) as well as three surveys commissioned by national government (Department of Tourism, Tourism Business Council of South Africa \& International Finance Corporation, 2020a, 2020b, 2020c). Of the 20 interviews in Bushbuckridge only one respondent (B19) stated that the lockdown regulations introduced by the South African government had been positive. When elaborating on these perceptions, respondents were asked about which specific regulations and in what specific ways their businesses were most considerably impacted. One of the most significant, mentioned by the majority of Bushbuckridge businesses, was the travel ban because of the area's orientation towards the high-end international tourist market: "The travel ban itself was a big hit" (B11). Most enterprises were significantly impacted by the international travel ban as nearly all businesses are overwhelmingly reliant on the international market. The interprovincial travel bans were also critical as the majority of domestic tourists to the area come from Gauteng. 
One of the two business which have a high proportion of domestic clients stated, the "interprovincial travel ban was the worst for us. We depend primarily on the Gauteng market" (B5). In addition, the South African government's introduction of several bans on the sale of alcohol ban was flagged by many as detrimental to their businesses. One respondent said "It's a holiday destination. People want to drink. Especially South Africans" (B18). Some encountered issues with guests demanding alcohol. "The alcohol ban was also significant. Level 4 was difficult. Guests would arrive thinking we would serve them alcohol" (B20).

\section{ENTERPRISE ADAPTIVE RESPONSES}

The Bushbuckridge tourism enterprise respondents were questioned about their adaptation strategies as a result of the pandemic, specifically the need to change or adjust their offerings, both in light of the pandemic and re-orienting their products towards the domestic tourism market. The primary adaptation strategy among businesses has been to reduce prices. The extent to which this was done varied based on the products offered. One respondent stated "We now have a very domestic rate" (B19). In addition, one 5-star lodge struggled with deciding how low to reduce their prices for the domestic market: "Once we introduced domestic rates, the lodge started being booked. Domestic clients, though, only started book once we hit the 'sweet spot' in terms of price reductions" (B18). Another said: "We've created lower rates that locals bite into" (B19). Some have introduced self-catering units. "We have introduced self-catering units specifically catering for locals" (B6). With the pandemic most businesses acknowledged that nearly all their 2020 clients are domestic tourists, albeit the revenue from these domestic tourists did not come close to making up for the missed revenue from international tourism. Many respondents pinpointed that their products are simply not geared for the domestic market. One operator of safari tours stated "South Africans like to self-drive and stay in the park. They don't want to pay for the safari experience." (B13). This sentiment was echoed by other safari tour operators who indicated that despite significant price reductions they struggle to get South African clients: "Even if you try, South Africans usually self-drive" (B11). In addition, some of the high-end lodges noted that South Africans are visiting the area because they have no other choice at the moment and that it probably will not sustain into the future, saying "Our current guests will probably end up going overseas in the future" (B18).

Several respondents noted issues faced in adapting their products, particularly prices. "Originally we gave large discounts for our luxury accommodation. One problem was the quality of guests really deteriorated, causing major problems. Once the police actually had to be called. Now we just give free upgrades on arrival. This has been really beneficial for word of mouth marketing. This usually gets mentioned in our reviews" (B12). The issues surrounding problems with 'specific types of guests' was echoed by others, "Specific self-catering units are reserved for local tourists as they are rowdier" (B6). Arguably, all business have had to adapt their business operations to the safety protocols: "We are very aware of COVID protocols" (B19). The challenges with this adjustment are discussed below. However, a number of respondents noted that tourism in the area is very COVID-friendly. One respondent stated "We have separate suites and outdoor activities which made it easier to adhere to protocols" (B20).

Another said that they have had to adapt somewhat stating "A little bit. COVID isn't as intense in this area [the Lowveld]. Everything is open, there are less cases here" (B19). Some establishments stated that they have been able to use the South African tourism market to experiment with different approaches "We've changed meal format from Breakfast, Lunch Dinner to Morning Tea, High Tea and dinner - We will probably keep this in the long run as it seems to be working better" (B10).

Another proceeded with the building of the guesthouse because she saw the opportunity to potentially have long-term guests who are working remotely: "I can also rent the guest house if needed, monthly" (B9). One of the budget accommodation operators, a backpacker hostel, stated that they built some facilities to accommodate a wider range of domestic tourists, since that market was increasing. "We are now trying to accommodate local business travellers with wifi in order for them to be able to work while staying on the premises" (B7). Several others discussed how they adapted their marketing strategies and gear it much more towards domestic tourists, for example "Marketing has been difficult as we originally oriented all our marketing towards the international market and have had to completely re-adjust" (B18). In terms of the primary challenges faced by local businesses in adjusting their product offerings, financial implications were the most prominent. Some noted costs caused by safety measures. "The cost implication of safety protocols are another issue - the cleaning, Personal Protective Equipment." (B18). Another noted that it is not only the cost implications of safety protocols but also the time needed for cleaning measures in accommodation establishments: "Cleanliness has a big impact. We used to spend 30 minutes cleaning each room each day, now it's up to two hours per room" (B19). Many Bushbuckridge respondents indicated that staffing has been a major issue, as they have had to cut staff or at least decrease hours of remaining staff members. Staff reductions are not only a result of the long closures during the various stages of lockdowns, but also due to the pressure to decrease prices. This was noted primarily by the lodges and up-scale game reserves. Given the price reductions, these enterprises are barely able to survive, yet alone produce profit, a situation that inevitably has caused many reductions in staff salaries or retrenchments. One game reserve respondent observed that they have currently decreased their prices by around 65\%: "All of our services and products are geared towards the international rate. We are struggling to provide the same product at $65 \%$ off of the standard rate. Staffing issues are particularly problematic." (B10) Although the game reserve operators expressed that they were grateful for any business, including from the domestic market, in the long-term the situation is viewed as not sustainable, a sentiment which was echoed by many lodges.

A further business challenge highlighted by several of the lodges is the seasonality of the domestic tourism market. South African domestic tourism consists of sets of travelers: weekend visitors from South Africa's economic heartland, Gauteng province, and visitors during holiday periods (most notably school holidays): "Midweek is very quiet with the domestic market. Most are weekend visitors" (B18). This is challenging, as the international market tended to make up for low periods, as they would travel at different times and often stay for longer periods. One lodge respondent said "South Africans are struggling to book ahead because of lack of clarity with school holidays" (B16). This is related, then to uncertainty in several aspects of life, preventing those from planning ahead. This is coupled with the clear fact that many people have lost part or all of their income as a result of the pandemic which has caused an economic crisis. Another respondent, a hotel operator, put it clearly "There are 
two problems. One is that people are scared to travel. Two is that people are careful as to how to spend their money" (B19).

Similarly, many noted the differences in booking patterns among domestic tourists versus their international counterparts. Several respondents indicated that South Africans tend not to book very far in advance. "Another big thing has been the growth in last minute bookings. It used to not be possible but it's possible now because of COVID" (B12). Another stated clearly that "Domestic tourists are very last minute in their booking" (B18). The problem businesses face with this, particularly in the current COVID-19 environment, is the need to ensure all the necessary preparations are in order for when visitors arrive. This includes ensuring adequate staff is available and on the premises: "Staffing is a major problem with last minute bookings" (B18). Then there is the necessary food and beverage requirements and that all facilities are adequately sanitized, among other concerns with last minute bookings, particularly when lodges are often sitting empty for periods of time. "Last minute bookings are hard to deal with. We need to make sure all the necessary staff is available and that the facilities are properly sanitized. It's even hard to make food orders with last minute bookings when the lodge is largely empty" (B16).

One notable challenge, which was discussed in detail by an operator of safari tours, was a lack of information on the wants and needs of the Black South African leisure tourism market. "If we are going to be dependent on the domestic market, we need to learn the Black market" (B13). It was noted that their requirements and wants, specifically in the context of naturebased and safari experiences, differed significantly from their typical international clientele. One additional challenge was issues with age restrictions implemented by South African National Parks (SANParks) on open-drive safari vehicles. "There are major issues with SANParks regulations. Especially with kids - Black families with very young children. Children under three years aren't allowed on open vehicles but the whole family needs to come on the trip" (B13). It was also indicated that the company had been able to access marketing studies which had examined the demands of other population groups (specifically mentioning the Indian South African market), and that they had pretty extensive knowledge of both the English and Afrikaans domestic tourism markets, but that there was little information they could access on the Black South African tourism market. This lack of insight was viewed as a significant challenge in trying to re-orient their products to cater to this emerging, and rapidly increasing, domestic tourism market. "Local cultures and beliefs are significant in understanding the market" (B13).

In relation to opportunities for the demands of the domestic tourism market the majority of respondents either said they do not see any opportunities, that the domestic market is unsustainable for their business models or that they are not really interested in expanding their domestic market share once the international market is re-introduced. "The lodge isn't built for South Africans. There's no self-catering. There's no braai areas. There's no TVs" (B14). A few businesses, however, specifically noted an increase in the Black South African tourism market, one which had not been as prevalent in previous years; indeed the limited engagement of Black South Africans with the country's nature-based tourism attractions is a theme highlighted in earlier works by Butler and Richardson (2013, 2015). One lodge manager observed: "There has been a big increase in the Black middle class coming to the area" (B12). Another lodge owner stated "Yes, we have had an amazing upturn in Black South Africans." (B6). Potential significant opportunities were identified in particular subsectors of this market. "A big market we've noticed is single Black women travelling in groups" (B13). Other enterprises expressed appreciation of the domestic market due to their role in sustaining the businesses during the pandemic. Several indicated that they had not thought about marketing to domestic tourists before but would continue to do so in future. For most enterprises, however, it appears that re-orienting completely towards a South African market was financially unsustainable in the long term. "All of our services and products are geared towards the international rate. We are struggling to provide the same product at $65 \%$ off of the standard rate. Staffing issues are particularly problematic" (B10). Another adaptation is that in light of price reductions given to local visitors, enterprises were able to use this time as an opportunity to try out new products and change existing products, stating "the South African market is sort of like guinea pigs. We have felt the freedom to try out re-orienting services and trying out new things, for example with the mеnu." At the game reserves and lodges it was noted South Africans are vocal about their complaints and concerns (B10 and B16). This, coupled with the fact that many South Africans have had experiences at other "bush" accommodation or safari experiences, meant that enterprises found the feedback useful. Respondent B10 noted that the South African market was one they never really had to explore before but that they are now thinking of providing South African rates into the future, using what they called "price apartheid." It was stated as follows: "The South African market has been so good to us in our time of need that we need to really look at them in the future" (B10). A game reserve respondent noted "There are talks of how good the domestic market has been to us. We will accommodate the domestic market going forward" (B20).

When asked if they planned to introduce any new products or offerings, the majority had no such plans. "Not now. We are saving all our Rands and cents until the market opens up properly" (B13). Many did indicate that they are re-orienting their website and marketing to attract more local tourists. Those who were introducing new products, in terms of the built environment, all had plans for expansion previously. One lodge operator, however, reported repurposing some accommodation units in order to allow for self-catering (B6). Several respondents are in the process of introducing new technology products. A safari tour respondent is in the process of developing a travel app in order to assist in planning trips and also do virtual guiding for those on self-drives. Another game reserve respondent had introduced virtual safari experiences during lockdown and currently are maintaining a YouTube channel which has grown exponentially and will hopefully encourage future visitors. "We also utilized our existing YouTube channel and created content during lockdown called 'Rangers in isolation' this is continuing with 'Mala Mala Safari Moments.' We went from 27,000 subscribers to 125,000 subscribers during lockdown" (B10).

Some respondents discussed ways in which they are trying to adapt technology to improve their products in the COVID-19 environment. The awareness of the contactless economy and a South African form of untact was clear: "There is a lot of possibility with technology. No touch tech. We are looking into using your phone as a key to get into your room" (B19). The same operator discussed the implementation of facilities for webinars and virtual conferences: "We are looking into installing facilities at the lodge to host webinars" (B19). Others are creating new products or looking into re-working previous products. A few are introducing more trips to places other than Kruger National Park such as surrounding local small towns with interesting features or activities that they feel might be appealing to a domestic market which has already spent time in Kruger National Park and in search of alternative local experiences: "We're thinking out of the box. We've created a Kaapsehoop 
Escarpment Tour. The domestic market seems to like things like the wild horses" (B13). Some enterprises are specifically catering to the Black South African leisure touirsm market, which they said is a relatively new and growing market for safari tourism, especially into Kruger National Park. One tour operator with a guest house stated "I'm now offering cheap day trips into the park and other tours such as hiking trips... Trying to orient towards community members - they can at least afford a cheap day trip" (B9). Another said that, if there are a certain number of guests, they are starting their visits to the park later, as they have seen that the market is seeking that type of experience. "We are noticing that there is no demand for early morning drives for the black market" (B13). She then discussed how the experience they offer is quite different. "They want to stop often, walk around, take selfies...They are very vocal when they are 'done' and ready to leave" (B13).

Many enterprises indicated a key adaptation response was business downsizing. The majority of respondents cited downsizing related to staffing. Several had to cut major portions of their staff, while many others have staff operating on part-time salaries. A lodge respondent stated "All staff is on 50\% salary and that's after staff were cut by 50\%" (B6). Other than that, some businesses have had to sell vehicles and some are on the verge of closing down. One of the game reserves has closed one of their camps completely and currently only operates one of the three camps regularly. "Currently only one camp, out of three, is operating regularly. One camp is completely closed and hasn't opened at all. The third camp is open as occupancy dictates" (B10). Another said that they had to close down their restaurant because of a lack of demand, especially with the liquor bans. "The restaurant was really struggling so we closed it" (B3). Others noted that they have had to restrict the number of people which engage in certain activities. "I have had to create limits on the number of passengers in the vehicles" (B8). Many, however, said that they have not downsized or removed products. "Not at all. That's why I don't want to go down in prices. I want to keep offering the same service" (B4). Several respondents echoed this sentiment, stating that despite the drop in prices, they continue to maintain the quality of service. "None of our standards dropped. We maintained standards with food, game drives, etc." (B20). Another respondent stated that they had downgraded their marketing. "Not really marketing to international travel anymore" (B9).

A further point brought up by one of the high-end game reserves is that they have had to cut their outreach community programmes: "Local communities are very reliant on the lodges, not only for employment. All our community outreach programmes have been completely stripped" (B20). Some respondents reflected on the increase in comradery and communication between local businesses as a result of the current pandemic and economic climate. Several respondents indicated the value of local enterprise cooperation and indicated aspects of increased communication between businesses has been useful, "Yes, it's a close community, sharing information on what's app regarding safety and regulations" (B7). This said, there did not seem to be many ways in which local businesses are not necessary working directly with one another nor repackaging products to encourage tourists to utilize a variety of services in the area. This is related to the context of these businesses, many of which are in direct competition with one another (i.e. different types of accommodation, different safari operators).

\section{FUTURE BUSINESS PROSPECTS AND GOVERNMENT INTERVENTION}

Questions about support interventions and government assistance elicited mixed responses especially in terms of the future of these businesses, what sort of support and interventions businesses would require in order to simply to survive and also in re-orienting towards the domestic market. There was a general consensus that the local tourism industry is being over-looked by government in terms of support a finding confirmed in other research (Rogerson and Rogerson, 2020b). The operators of a game reserve expressed the viewpoint that :Government needs to be open to discussion with the tourism industry. We feel we are not being listened to. The industry feels neglected" (B20). This sentiment was echoed by many respondents who demonstrated a general lack of faith in government intervention overall, with one respondent stating that in response to tourism support, government is "making a lot of noise but not actually doing anything" (B9).

Some businesses provided broad answers on what would be helpful forms of support, the most prominent of which related to a need for direct financial assistance, a confirmation of results disclosed in national surveys of tourism enterprises (Department of Tourism et al., 2020a, 2020b, 2020c). In terms of intervention from local government, the majority of responses indicated the need for breaks on rates and taxes, where applicable, and an increase in local marketing. Many respondents, however, felt that local government has little authority or capacity to do much that would actually help tourism businesses, with one respondent blatantly stating "Local government can't do much" (B5). Similar sentiments were expressed by others: "Tax breaks would be good. But I don't think that is going to happen" (B20). Another respondent noted a series of issues with service delivery in the Bushbuckridge area: "Sewage and roads, service delivery are in disarray in Bushbuckridge. We've been here for 11 years and have tried to get assistance but to no avail" (B12). The biggest local concern, among nearly all respondents in the area, was with the quality of the roads. Although they were asked about infrastructure assistance in the context of national government support, there was a clear consensus among all businesses that the state of the roads in the area was problematic. This issue has been exacerbated by recent excessive rains, coupled with the impact from tropical storm Eloise, which hit the area in early 2021. However, once again, there was little faith in local government to rectify these issues. "Roads need to be fixed. But I don't see that happening" (B3). Others mentioned concerns over power outages which is a national problem in South Africa. "Eskom! Keep the power on and at a lower rate" (B5). Another said "Infrastructure...Roads! Power! We are often running on a generator which increases expenses" (B20).

Another support intervention identified as essential by several businesses related to government and marketing. A game reserve respondent "Our biggest concern right now is the press coverage around the South African variant. We need a major $P R$ campaign to show the world that the variant is not that bad, that South Africa is handling the virus relatively well and that our tourism products are very safe." (B10) This viewpoint was echoed by other enterprises in the Bushbuckridge area. The sentiment arose that SA Tourism - the national marketing agency - has not been proactive in their marketing strategies. "South Africa is a good place to travel for COVID...[but] SA Tourism have done sweet b... all to show how compliant South Africa is and that the actual rates are much lower than the rest of the world" (B13). Although they are grateful for the domestic market, the quantity and costs of these operations simply will not survive without the international market. "We need better marketing of the success of South Africa's response to COVID. We need to tell the rest of the world... We need to demonstrate that a lot of 
the activities are "COVID friendly", we're reducing the number of passengers on game drives, etc." (B12). This was elaborated on by suggesting incentives for travel. "South Africa needs to get its butt into gear with incentives for travel" (B12).

In terms of support from national government beyond infrastructure and marketing, the primary request among these businesses was financial relief, in one way or another. To further this point, when asked about which support or intervention would be the most important in the short-term (the next 12 months) nearly all businesses stated that financial assistance or relief is, by far, the most important support needed in the short-term, in order for them simply to keep afloat. Without support, many tourism employees are having their salaries cut significantly or otherwise have been retrenched. A safari tour operator stated "We have no money to pay our staff and they are literally starving." (B15). Others suggested alternative mechanisms for supporting businesses financially, for example that income tax breaks for tourism operators would be helpful. "Reduction in tourism taxes, taxes for tourism businesses" (B7). A few mentioned the concerns over payments, specifically for cars and other fixtures needed for their businesses. Another safari tour operator said "Lots of people had to sell vehicles because they couldn't afford the payments." (B 11). Another said "Any financial relief - car installments. I'm currently running on negative" (B9).

A general distrust of government and government support was evident among these enterprises, with one stating that "There's a lot they can do. Give more thought to tourism in general but it has been neglected so far" (B20). Businesses provided a number of different suggestions as to how the government might be able to assist in supporting tourism businesses financially. Many of these included direct financial assistance or government subsidized loans. All but one of the businesses interviewed were whiteowned and all but three were SMMEs. Nearly all SMME owners (including the black-owned business) said that they struggled to get government relief (B9). Those who did receive some compensation said that it was minimal and not what was promised; many indicated that funding did not come close to covering operating costs, let alone enough money to support staff. One of the most controversial issues, particularly among white-owned SMMEs, was that they did not qualify for government funding because they are not majority black-owned and therefore disqualified for support funding as a consequence of government initiatives for 'transformation' and preferencing of Black Economic Empowerment (BEE) (see Abrahams, 2019; Rogerson and Rogerson, 2020b). As was observed by one safari lodge owner: "It would've been helpful if the government helped financially - even loans. But BEE restricts us" (B14). With the size of these businesses, the majority would struggle to get BEE accreditation. "I'm foreign and white so I don't qualify for any help" (B4). "In a situation like this, everyone needs help" (B11). Many of the concerns noted among those who had similar complaints, is that they employ large staff, the vast majority of whom are Black and from the local Bushbuckridge community: " $80 \%$ of our staff is Black and from the local community" (B14).

In light of the current situation, and a discussion about potential support and interventions, respondents were asked what they felt were their prospects for the next 12 months without any support or interventions. Overall, the responses were not promising for the local tourism economy. One safari tour respondent said that they had already decided to close their business "We are closing down. We are emigrating," (B11) while a lodge owner already had put the property on the market and another safari tour operator stated that they were on the verge of shutting down (B15). Out of the 20 businesses, only four (B5, B10, B12 and B19), confidently, feel that they will survive the year without support, albeit all said that it is dependent on no new restrictions being put in place and that despite survival, there would likely be major cuts, particularly in staff. These are predominantly large established businesses (in the cases of B10 and B19) or those who are inputting income from other sources (namely B12, the owner of which owns a chicken farm). "Alternative income has sustained us" (B12). The final respondent runs a wildlife interaction centre which was already primarily dependent on domestic tourists (B5). Of note is that the only other operator which has a majority domestic clientele is concerned about business because of the nature of the changes in tourism demand (i.e. a lack of events in the area) and difficulties in taking clients on cross-border trips. Some respondents stated they are not sure of future survival, with comments such as "We're hanging in there" (B7) or "Just try to do it day by day" (B2). The remaining respondents stated that without intervention or a significant uptick in visitors to the area (which several noted is dependent on at least some return of the international market) they would not survive.

"Four more months, then we're closed." (B6)

"Chances of survival are low. Trying to do anything to keep afloat." (B8)

"Closing business... Very little hope in the future." (B11)

"We won't have a business...I haven't had remuneration in 13 months. That is the state of where people are." (B13)

For the luxury lodges, in particular, the pool of possible clients is small: "The South African market for luxury is already small and it will get smaller if things continue as they are going" (B19). Another said "From August to December, we were full every weekend. A bit during the week from government. It covered costs but we didn't make a profit. Nothing extra" (B14). Some gave exact timelines for when they expect their business to close without support, most of which fell between the next four and 10 months, meaning they do not foresee survival to the next December/January holiday season. "We are in recovery mode. At the end of the day, charging 33\% of our normal rates will not let us continue. We were hoping to survive for the next 6-12 months. Now it's looking like it will take 2-3 years to get back to where we were" (B20). Many enterprises were highly pessimistic offering statements such as "If you can do something else, do it! Tourism isn't coming back in the near future" (B11). This said, there was a strong sentiment from many respondents about the necessity for the survival of tourism in the area. Safari tourism and that linked to Kruger National Park is considered some of the most iconic in the country. As one respondent stated: "Without support more and more places will close down. Game Reserves can't fail. They are part of the South African psyche" (B10). It was argued that by emphasizing the importance of tourism in the South African economy: "I know this is a pandemic, it's serious, but we need to save what we can. Use the money towards businesses that will save South Africa. Tourism is one of them" (B10).

\section{CONCLUSION}

The crisis precipitated by COVID-19 is unprecedented in relation to past crises that have impacted tourism such as those from natural disasters or terrorism. The COVID-19 pandemic is observed to have global and deeper consequences with the potential for massive changes in the organization and architecture of tourism systems. For some observers "it is critical for 
tourism as a complex adaptive system to continue to respond, adjust, and adapt with resiliency against COVID-19" (Kwok and Koh, 2021: 390). Accordingly, in the myriad of COVID-19 related research investigations one important focus must be upon investigating the responses of tourism businesses to the pandemic. How business owners are seeking to adapt or coping with the uncertainties around COVID-19 can contribute towards thinking around tourism recovery planning. The objective in this study was to examine enterprise adaptation in a nature tourism destination in South Africa that is A concentrated on the market of high-end international tourism. It is revealed that adaptation to the crisis has been challenging because of the financial impacts experienced by these enterprises in the wake of minimal government support. The enterprise adaptive responses have included staff reductions and wage cuts, adjustments towards the domestic market through price cutting, changes in marketing as well as adjusted tourism product offerings towards an emerging Black middle class domestic market. Of critical significance is the finding that these adaptive measures cannot replace the revenues formerly generated from the international tourism market. Seemingly, without a change in government policy and the offer of direct government financial support there is a danger that in the short term the tourism product base will be diminished as many lodges and other tourism businesses are in danger of permanent closure. Due to the significance of tourism for the local economy, and particularly for employment among many community members, the implications of closure of a significant proportion of businesses is devastating for the region. The results demonstrate some potential adaptation strategies but more work is needed to understand the long-term potential of these strategies to sustain businesses. The perspectives of domestic leisure tourists in South Africa would assist in gaining a better understanding of the potential for domestic tourism to maintain the local tourism economy as the pandemic persist. Although significant, this data is clearly limited in its scope and would benefit from additional research going forward both on the impacts of the pandemic on the local economy more broadly but also future research on the state of these businesses within the next year.

\section{Acknowledgements}

South Africa's Department of Tourism is thanked for funding this research project. Arno Booyzen is acknowledged for cartographic work. Sue Rose and Robbie, Dawn and Skye Norfolk provided inputs to the analysis.

\section{REFERENCES}

Abrahams, D. (2019). Transformation of the tourism sector in South Africa: A possible growth stimulant? GeoJournal of Tourism and Geosites, 26 (3), 821-830. https://doi.org/10.30892/gtg.26312-400

Alonso, A.D., Bressan, A., Kok, S.K., Sakellarios, N., Koresis, A., O’Shea, M., Solis, M.A.B., \& Santoni, L.J. (2021). Facing and responding to the COVID-19 threat-an empirical examination of MSMEs. European Business Review, https://doi.org/10.1108/EBR-09-2020-0231

Alonso, A.D., Kok, S.K., Bressan, A., O’Shea, M., Sakellarios, N., Koresis, A., Solis, M.A.B., \& Santoni, L.J. (2020). COVID-19, aftermath, impacts, and hospitality firms: An international perspective. International Journal of Hospitality Management, 91, 1026554. https://doi.org/10.1016/j.ijhm.2020.102654

Bae, S.Y., \& Chang, P.J. (2020). The effect of coronavirus disease-19 (COVID-19) risk perception on behavioural intention towards 'untact' tourism in South Korea during the first wave of the pandemic (March 2020). Current Issues in Tourism.. https://doi.org/10.1080/13683500.2020.1798895

Bianchi, R.V. (2020). COVID-19 and the potential for a radical transformation of tourism? ATLAS Tourism and Leisure Review 2020-2, 80-86.

Bressan, A., Duarte Alonso, A. \& Kok, S.K. (2021). Confronting the unprecedented: micro and small businesses in the age of COVID-19. International Journal of Entrepreneurial Behavior \& Research, 27 (3), 799-820. https://doi.org/10.1108/IJEBR-09-2020-0602

Brouder, P. (2020). Reset redux: Possible evolutionary pathways towards the transformation of tourism in a COVID-19 world. Tourism Geographies, 22 (3), 484-490. https://doi.org/10.1080/14616688.2020.1760928

Buheji, M., da Costa Cunha, K., Beka, G., Mavrić, B., de Souza, Y.L., da Costa Silva, S.S., Hanafi, M., \& Yein, T.C. (2020). The extent of COVID-19 pandemic socio-economic impact on global poverty: A global integrative multidisciplinary review. American Economic Review, 10 (4), 213-224. https://doi.org/10.5923/j.economics.20201004.02

Bushbuckridge Local Municipality (2017). 2017/22 Final Integrated Development Plan. Bushbuckridge: Bushbuckridge Local Municipality.

Butler, G., \& Richardson, S. (2013). Young Sowetans and tourism participation: Identifying opportunities to develop further engagement with South African national parks. Journal for Physical Health Education, Recreation and Dance, 18 (spl. 2), 309-322. https://doi.org/10.10520/EJC143191

Butler, G., \& Richardson, S. (2015). Barriers to visiting South African national parks in the post-apartheid era: Black South African perspectives from Soweto. Journal of Sustainable Tourism, 23 (1), 146-166. https://doi.org/10.1080/09669582.2014.940045

Deb, S.K., \& Nafi, S.M. (2020). Impact of COVID-19 pandemic on tourism: Recovery proposal for future tourism. GeoJournal of Tourism and Geosites, 33 (4) Supplement, 1486-1492. https://doi.org/10.30892/gtg.334spl06-597

Gössling, S., Scott, D., \& Hall, C.M. (2021). Pandemics, tourism and global change: A rapid assessment of COVID-19. Journal of Sustainable Tourism, 29 (1), 1-20. https://doi.org/10.1080/09669582.2020.1758708

Grech, V., Grech, P., \& Fabri, S. (2020). A risk balancing act - Tourism competition using health leverage in the COVID-19 era. International Journal of Risk \& Safety in Medicine, 31 (3), 121-130. https://doi.org/10.3233/JRS-200042

Gursoy, D., \& Chi, C.G. (2020). Effects of COVID-19 pandemic on hospitality industry: Review of the current situation and research agenda. Journal of Hospitality Marketing \& Management, 29 (5), 527-529. https://doi.org/10.1080/19368623.2020.1788231

Hall, C.M., Scott, D., \& Gössling, S. (2020). Pandemics, transformations and tourism: Be careful what you wish for. Tourism Geographies, 22 (3), 577-598. https://doi.org/10.1080/14616688.2020.1759131

Higgins-Desbiolles, F. (2020a). Socialising tourism for social and ecological justice after COVID-19. Tourism Geographies, 22 (3), 610-620. https://doi.org/10.1080/14616688.2020.1757748

Higgins-Desbiolles, F. (2020b). COVID-19 and tourism: reclaiming tourism as a social force?. ATLAS Tourism and Leisure Review, 2020-2, 65-73.

Hockings, M., Dudley, N., Elliott, W., Ferreira, M.N., Mackinnon, K., Pasha, M.K.S., Phillips, A., Stolton, S., Woodley, S., Appleton, M., Chassot, O., Fitzsimons, J., Galliers, C., Kroner, R.G., Goodrich, J., Hopkins, J., Jackson, W., Jonas, H., Long, B., Mumba, M., Parrish, J., Paxton, M., Phua, C., Plowright, R., Rao, M., Redford, K., Robinson, J., Rodriguez, C.M., Sandwith, T., Spenceley, A., Stevens, C., Tabor, G., Troeng, S., Willmore, S., \& Yang, A. (2020). COVID-19 and protected and conserved areas. The Parks Journal, 26 (1), 7-24. https://doi.org/10.2305/IUCN.CH.2020.PARKS-26-1MH.en

Khoza, P.N. (2016). Ecotourism supply and demand analysis in Bushbuckridge. M. Tech thesis (Tourism and Hospitality Management), Tshwane University of Technology, Pretoria.

Kock, F., Nǿrfelt, A., Josiassen, A., Assaf, A.G., \& Tsionas, M.G. (2020). Understanding the COVID-19 psyche: The evolutionary tourism paradigm. Annals of Tourism Research, 85, 103053. https://doi.org/10.1016/j.annals.2020.103053 
Kusumaningrum, D.A., \& Wachyuni, S.S. (2020). The shifting trends in travelling after the COVID-19 pandemic. International Journal of Tourism and Hospitality Review, 7 (2), 31-40. https://doi.org/10.18510/ijthr.2020.724

Kvirkvelia, N., \& Tsitsagi, M. (2021). Impact of COVID-19 on tourism in Georgia - An overview. Georgian Geographical Journal, 1 (1), $27-33$.

Kwok, A.O.J., \& Koh, S.G.M. (2021). Lux in tenebris: Content analysis of Covid-19 research. In P. Jose, M. Sigala, P. Whitelaw \& I. Ye (Eds.), Transformations in Uncertain Times: Future Perfect in Tourism, Hospitality and Events: Proceedngs of the $31^{\text {st }}$ Annual Conference, Council for Australasian University Tourism and Hospitality Education (CAUTHE). Adelaide: CAUTHE, 386-391.

Lubbe, B.A., Douglas, A., Fairer-Wessels, F., Kruger, E., \& Geldenhuys, E. (2016). Matching tourism supply and demand: An analysis of how tourism products meet the needs of emerging domestic markets in selected regions in South Africa. Travel and Tourism Research Association: Advancing Tourism Research Globally. 25.

Mukwarami, S., Mukwarami, J., \& Tengeh, R.K. (2020). Local economic development and small business failure: The case of a local municipality in South Africa. International Journal of Business and Globalisation, 25 (4), 489-502. https://doi.org/ 10.1504/IJBG.2020.10031306

Nicola, M., Alsafi, Z., Sohrabi, C., Kerwan, A., Al-Jabir, A., Iosifidis, C., Agha, M., \& Agha, R. (2020). The socio-economic implications of the COVID-19 pandemic: A review. International Journal of Surgery, 78, 185-193. https://doi.org/10.1016/j.ijsu.2020.04.018

Niewiadomski, P. (2020). COVID-19: From temporary de-globalisation to a rediscovery of tourism? Tourism Geographies, 22 (3), $651-656$. https://doi.org/10.1080/14616688.2020.1757749

Niyimbanira, F. (2016). Characterisation of time-related underemployment in a South African municipality: A case of Bushbuckridge, Mpumalanga province. International Journal of Social Sciences and Humanity Studies, 8 (1), 116-132.

Nkuna, L. (2017). Local economic development strategy implementation within Bushbuckridge local municipality. PhD dissertation, University of Zululand.

Persson-Fischer, U., \& Liu, S. (2021). The impact of a global crisis on areas and topics of tourism research. Sustainability, 13 (2), 906. https://doi.org/10.3390/su13020906

Richards, G., \& Morrill, W. (2021). The challenge of COVID-19 for youth travel. Revista Brasileiros de Estudos Turísticos, 11, 1-8.

Rogerson, C.M. (2017). Unpacking directions and spatial patterns of VFR travel mobilities in the global South: Insights from South Africa. International Journal of Tourism Research, 19, 466-475. https://doi.org/10.1002/jtr.2101

Rogerson, C.M., \& Baum, T. (2020). COVID-19 and African tourism research agendas. Development Southern Africa, 37 (5), $727-741$. https://doi.org/10.1080/0376835X.2020.1818551

Rogerson, C.M., \& Rogerson, J.M. (2020a). COVID-19 tourism impacts in South Africa: Government and industry responses. GeoJournal of Tourism and Geosites, 31 (3), 1083-1091. https://doi.org/10.30892/gtg.31321-544

Rogerson, C.M., \& Rogerson, J.M. (2020b). COVID-19 and tourism spaces of vulnerability in South Africa. African Journal of Hospitality, Tourism and Leisure, 9 (4), 382-401. https://doi.org/10.46222/ajhtl.19770720-26

Rogerson, C.M., \& Rogerson, J.M. (2021a). Looking to the past: The geography of tourism in South Africa during the pre-COVID-19 era. In C.M. Rogerson \& J.M. Rogerson (Eds.), Urban Tourism in the Global South: South African Perspectives. Cham, Switzerland: Springer Nature.

Rogerson, C.M., \& Rogerson, J.M. (2021b). COVID-19 and changing tourism demand: Research review and policy implications for South Africa. African Journal of Hospitality, Tourism and Leisure, 10 (1), 1-21. https://doi.org/10.46222/ajhtl.19770720-83

Rogerson, J.M. (2021). Tourism business responses to South Africa's COVID-19 pandemic emergency. GeoJournal of Tourism and Geosites, 35 (2), 279-281. https://doi.org/10.30892/gtg.31321-544

Rutynskyi, M., \& Kushniruk, H. (2020). The impact of quarantine due to COVID-19 pandemic on the tourism industry in Lviv (Ukraine). Problems and Perspectives in Management, 18 (2), 194-205. https://doi.org/10.21511/ppm.18(2).2020.17

Seyitoğlu, F., \& Ivanov, S. (2020). Service robots as a tool for physical distancing in tourism. Current Issues in Tourism. https://doi.org/10.1080/13683500.2020.1774518

Shackleton, C. (2000). Comparison of plant diversity in protected and communal lands in the Bushbuckridge lowland, savanna, South Africa. Biological Conservation, 94 (3), 273-285. https://doi.org/10.1016/S0006-3207(00)00001-X

Sharma, G.D., Thomas, A., \& Paul, J. (2021). Reviving tourism industry post-COVID-19. Tourism Management Perspectives, $37,100786$. https://doi.org/10.1016/j.tmp.2020.100786

Sigala, M. (2020). Tourism and COVID-19: Impacts and implications for advancing and resetting industry and research. Journal of Business Research, 117,312-321. https://doi.org/10.1016j.jbusres.2020.06.015

Spalding, M., Burke, L., \& Fyall, A. (2020). Covid-19: Implications for nature and tourism. Anatolia. https://doi.org/10.1080/13032917.2020.1791524

Sucheran, R. (2021). Preliminary economic impacts of the COVID-19 pandemic on the hotel sector in South Africa. African Journal of Hospitality, Tourism and Leisure, 10 (1), 115-130.

Thornton, R. (2002). Environment and land in Bushbuckridge, South Africa. In L. Zarsky (ed.), Human Rights and the Environment: Conflicts and Norms in a Globalizing World. London: Earthscan, 219-240.

Verma, S., \& Gustafsson, A. (2020). Investigating the emerging COVID-19 research trends in the field of business and management: A bibliometric analysis approach. Journal of Business Research, 118, 253-261. https://doi.org/10.46222/ajhtl.19770720-90

Wolff, K., Larsen, S., \& Øgaard, T. (2020). How to define and measure risk perceptions. Annals of Tourism Research, 79, 102759. https://doi.org/10.1016/j.annals.2019.102759

Wood, A.G. (2021). Introduction: Travel histories checkered past as prelude to future catastrophe?. In A.G. Wood (Ed.). The Business of Leisure: Tourism History in Latin America and the Caribbean (pp. 1-20). Lincoln, Nebraska, USA: University of Nebraska Press.

Zenker, S., \& Kock, F. (2020). The coronavirus pandemic: A critical discussion of a tourism research agenda. Tourism Management, 81, 104164. https://doi.org/10.1016/j.tourman.2020.104164

*** Department of Tourism, Tourism Business Council of South Africa \& International Finance Corporation (2020a). Tourism Industry Survey of South Africa: COVID-19: Impact, Mitigation and the Future. Pretoria: Department of Tourism.

*** Department of Tourism, Tourism Business Council of South Africa \& International Finance Corporation (2020b). Tourism Industry Survey of South Africa: COVID-19: Preparedness for Reopening. Pretoria: Department of Tourism.

*** Department of Tourism, Tourism Business Council of South Africa \& International Finance Corporation (2020c). Tourism Industry Survey of South Africa: COVID-19: Reopening. Pretoria: Department of Tourism.

*** OECD (2020a). COVID-19 and Africa: Socio-Economic Implications and Policy Responses. Paris: OECD Policy Responses to Coronavirus.

*** OECD. (2020b). The Future of Tourism in Natural Areas: Impact, Governance, Financing. Paris: OECD.

*** UNCTAD (2020). COVID-19 and Tourism: Assessing the Economic Consequences. Geneva: UNCTAD.

*** UNWTO (2020). UNWTO Recommendations on Tourism and Rural Development: A Guide to Making Tourism An Effective Tool For Rural Development. Madrid: UNWTO. 